\title{
Results of Microvascular Decompression Surgery in the Treatment of Trigeminal Neuralgia
}

\section{Trigeminal Nevralji Tedavisinde Mikrovasküler Dekompresyon Cerrahisinin Sonuçları}

\author{
${\text { Mehmet } \operatorname{Seçer}^{1} \mathbb{D}, \text { Aykut Gökbel }}^{2}$
}

${ }_{2}$ Department of Neurosurgery, Alaaddin Keykubat University, Antalya, Turkey

Department of Neurosurgery, Derince Education and Research Hospital, Kocaeli, Turkey

Cite as: Seçer M, Gökbel A. Results of microvascular decompression surgery in the treatment of trigeminal neuralgia. Kocaeli Med J 2021;10(2):69-73.

\begin{abstract}
INTRODUCTION: Trigeminal neuralgia (TN) develops as a result of the trigger of one or more branches of the trigeminal nerve by stimuli. Most cases of TN are usually caused by compression of the trigeminal nerve root, within a few millimeters from its exit from the pons. In this study, we aimed to present our experience regarding the microvascular decompression surgical approach and its results in the treatment of patients who applied to the clinic with a diagnosis of TN and who did not respond to any of the treatments. METHODS: Microvascular decompression (MVD) surgery was performed on a total of 7 patients with TN who applied to the clinic between 2020 and 2021, and the information of the patients was retrospectively evaluated using surgery reports, epicrisis, and magnetic resonance images (MRI).

RESULTS: It was observed that all 7 patients with TN were initially administrated carbamazepine and/or oxcarbazepine, implemented radiofrequency thermocoagulation treatment and gamma knife radiosurgery. Subsequently, all the patients underwent MVD surgery. No complications developed in the postoperative period and complaints of $\mathrm{TN}$ in all patients completely resolved in the early period. DISCUSSION AND CONCLUSION: In patients who are unresponsive to treatments, thin-section 'constructive interference of steady state (CISS)' sequence cranial MRI are useful to detect trigeminal nerve compression caused by intracranial pathologies, and MVD surgery is important in the treatment.
\end{abstract}

Keywords: trigeminal nerve, trigeminal neuralgia, microvascular decompression surgery

Öz

GÍRIŞ ve AMAÇ: Trigeminal nevralji (TN), trigeminal sinirin bir veya daha fazla dalının uyaranlar tarafından tetiklenmesi sonucu gelişir. Çoğu TN vakası genellikle trigeminal sinir kökünün pons’tan çıkışından birkaç milimetre sonra kompresyonundan kaynaklanır. Bu çalışmada, TN tanısıyla kliniğe başvuran ve hiçbir tedaviye yanıt vermeyen hastaların tedavisinde mikrovasküler dekompresyon cerrahisi yaklaşımı ve sonuçları ile ilgili deneyimlerimizi sunmayı amaçladık.

YÖNTEM ve GEREÇLER: 2020-2021 yılları arasında kliniğe başvuran toplam 7 TN'li hastaya mikrovasküler dekompresyon (MVD) cerrahisi uygulandı ve hastaların bilgileri geriye dönük olarak cerrahi raporları, epikrizleri ve manyetik rezonans görüntüleri (MRG) kullanılarak değerlendirildi.

BULGULAR: TN'li 7 hastanın hepsine başlangıçta karbamazepin ve/veya okskarbazepin, radyofrekans termokoagülasyon tedavisi ve gamma knife radyocerrahi uygulandığı görüldü. Ardından tüm hastalara MVD cerrahisi uygulandı. Postoperatif dönemde komplikasyon gelişmedi ve tüm hastalarda TN şikayetleri erken dönemde tamamen düzeldi.

TARTIŞMA ve SONUÇ: Tedaviye yanıt vermeyen hastalarda ince kesit 'constructive interference of steady state (CISS)' sekanslı kraniyal MRG intrakraniyal patolojilerin neden olduğu trigeminal sinir kompresyonunu saptamak için yararlıdır ve MVD cerrahisi tedavide önemlidir.

Anahtar Kelimeler: trigeminal sinir, trigeminal nevralji, mikrovasküler dekompresyon cerrahisi
Geliş tarihi / Received:

21.05.2021

Kabul tarihi / Accepted:

20.06.2021

Sorumlu Yazar/Corresponding Author: Aykut Gökbel

Department of Neurosurgery, Derince Education and Research Hospital, Kocaeli, Turkey aykutgokbelnrs@gmail.com ORCID: 0000-0002-9332-3321

M. Seçer 0000-0001-9521-2476 


\section{INTRODUCTION}

Trigeminal neuralgia (TN) develops when one or more branches of the trigeminal nerve is triggered by stimuli. It is characterized by sudden onset, short-lasting, unilateral, and generally electric shock-like episodes of pain $(1,2)$. It is common in the elderly population and has an annual incidence rate between 4 to 13 per 100,000 people $(1,3,4)$. It affects women $(60 \%)$ more than men (40\%) (5-7). The mean age of onset of TN is reported to be $53-57$ years (5-7).

The trigeminal nerve begins on the medial-lateral surface of the pons and its sensory ganglion (Gasserian ganglion), it is located in the Meckel's cave on the floor of the middle cranial fossa. The three main branches of the trigeminal nerve are ophthalmic, maxillary, and mandibular (1).

TN is divided into two types, primary (classical) and secondary TN (5). Approximately, $80-90 \%$ of the TN cases are thought to be classical TN, caused by vascular compression $(1,8,9)$. Most cases of classic TN are reported to be caused by compression of the trigeminal nerve root, usually a few millimeters after its entrance into the pons $(1,8)$. Thin-section magnetic resonance imaging (MRI) is used for the diagnosis of classical TN, because MRI is the most appropriate method to evaluate for any distortion, push, and atrophy caused by compression of the vessel $(5,10)$. The first line of treatment of classical TN is pharmacological treatment (1).

In this study, we aimed to present our experience regarding the microvascular decompression (MVD) surgical approach and its results in patients who applied to our clinic with a diagnosis of TN with persistent pain despite medical and ablative treatment.

\section{MATERIALS AND METHODS}

MVD surgery was applied to a total of seven TN cases who applied to the clinic between 2019 and 2021, and the information of the cases was retrospectively evaluated using surgery reports, epicrisis, and MRI reports. The study was approved by the ethics committee of Health Sciences University Derince Training and Research Hospital (project number 2021/41). Table 1 shows the preoperative and postoperative demographic data of our patients.

\section{SURGICAL TREATMENT}

After the patient was placed in the lateral park bench position and the Mayfield skull clamp was placed in the appropriate position, the surgery was initiated with an incision suitable for the suboccipital retrosigmoid approach. The bone flap was expanded to the margin of the transverse sinus and sigmoid sinus with a high-speed drill. Then the dura was opened. The cerebrospinal fluid (CSF) was carefully drained and we proceeded extra-axially. An aspirator was used as a dynamic retractor to avoid the use of fixed retractors. The trigeminal nerve was exposed following the arachnoid dissection in the cerebellopontine cistern. The neurovascular relationship was carefully examined and it was observed that the superior cerebellar artery (SCA) in 4 patients, the anterior inferior cerebellar artery (AICA) in 2 patients, and the SCA + petrosal vein (PV) in 1 patient was compressing the trigeminal nerve (figure 1). Vascular structures compressing the trigeminal nerve were removed from the neural tissue using microsurgical techniques. A Teflon sponge was placed between the compressive vascular structures and the trigeminal nerve (figure 2).After hemostasis was achieved, the dura was closed.

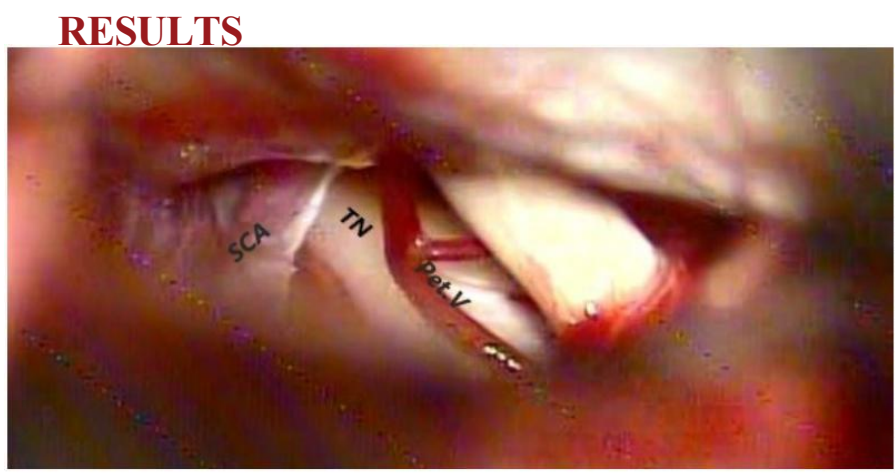

Figure 1: Superior cerebellar artery (SCA) and petrosal vein (Pet.V) attached to the trigeminal nerve (TN)

Table 1. Clinical characteristics of patients undergoing microvascular decompression (MVD) surgery

\begin{tabular}{lccccccc}
\hline $\begin{array}{l}\text { Patient } \\
\text { No }\end{array}$ & $\begin{array}{c}\text { Age (year) } \\
\text { /Gender }\end{array}$ & Side & Affected Division & $\begin{array}{c}\text { The Artery } \\
\text { Causing Pressure }\end{array}$ & Surgical Outcome & Complications & $\begin{array}{l}\text { Follow-up } \\
\text { Month(s) }\end{array}$ \\
\hline $\mathbf{1}$ & $46 / \mathrm{F}$ & Left & V1 & SCA & Painless & None & 12 \\
$\mathbf{2}$ & $48 / \mathrm{F}$ & Right & V1 & SCA & Painless & None & 14 \\
$\mathbf{3}$ & $49 / \mathrm{F}$ & Right & V1+V2 & SCA & Painless & None & 12 \\
$\mathbf{4}$ & $51 / \mathrm{M}$ & Left & V2 & AICA & Painless & None & 18 \\
$\mathbf{5}$ & $57 / \mathrm{M}$ & Right & V2-V3 & SCA & Painless & None & 16 \\
$\mathbf{6}$ & $53 / \mathrm{M}$ & Right & V2-V3 & AICA & Painless & CSF leak & 15 \\
$\mathbf{7}$ & $54 / \mathrm{F}$ & Left & V2-V3 & SCA + PV & Painless & None & 14
\end{tabular}

Clinical features of patients undergoing MVD surgery V1: Ophthalmic branch of the trigeminal nerve, V2: Maxillary branch of the trigeminal nerve, V3: Mandibular branch of trigeminal nerve SCA: superior cerebellar artery, AICA: Anterior inferior cerebellar artery, PV: Petrosal vein, F: Female, M: Male. 


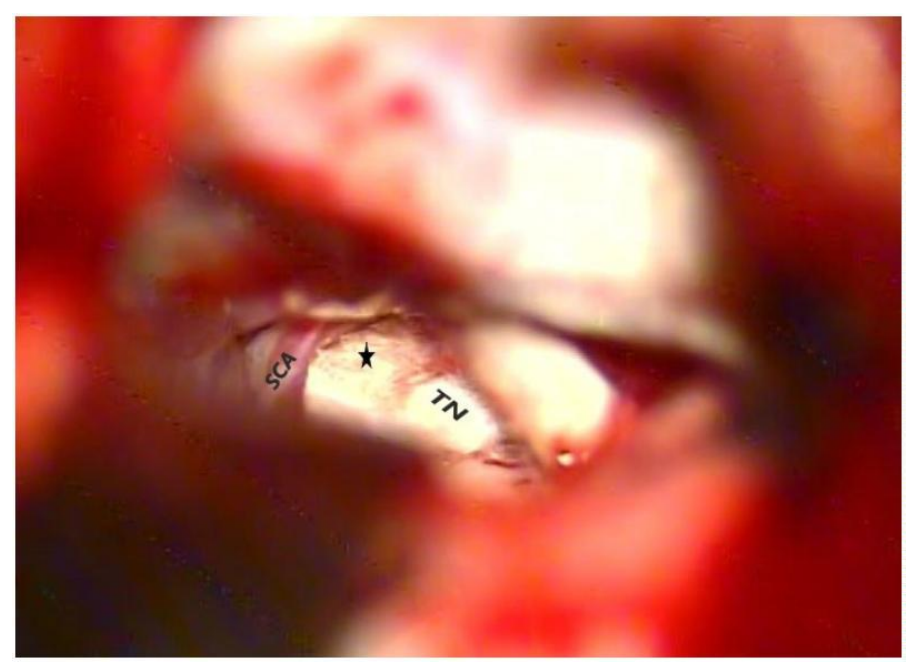

Figure 2: * Teflon placed between the vascular structures separated by the trigeminal nerve (TN), SCA: superior cerebellar artery

It was found that the 7 patients with $\mathrm{TN}$ had received medical treatment for a long time before they were admitted to the clinic. They had received several interventional treatments without, resolution of their complaints. It was observed that the patients were initially administrated carbamazepine as part of their medical treatment; however when symptoms did not resolve, the carbamazepine was switched to drugs containing oxcarbazepine. Additionally, these 7 patients received radiofrequency thermocoagulation treatment and gamma knife radiosurgery. Trigeminal nerve compression was diagnosed on thin-section 'constructive interference of steady state (CISS)' sequence cranial MRI in these patients who had applied to our clinic due to non-resolution of their symptoms. Subsequently, all the patients underwent microvascular decompression surgery. No complications developed in the postoperative period and complaints of TN in all patients completely resolved in the early period.

\section{DISCUSSION}

Vascular compression of the trigeminal nerve is the most common cause of primary TN (11-13). In most patients with classical $\mathrm{TN}$, pharmacological treatment is the first line of treatment. Surgery is considered for patients who are refractory to medical treatment (1). Carbamazepine is recommended as the initial treatment in patients with classic TN. The starting dose of carbamazepine is 100 to $200 \mathrm{mg}$ twice daily. The maximum recommended total dose is $1200 \mathrm{mg}$ per day (1).

Oxcarbazepine is recommended for patients who do not respond to or cannot tolerate carbamazepine. It can be started with a total dose of $600 \mathrm{mg}$ twice daily. The dose can be increased to 1200 to $1800 \mathrm{mg}$. For patients who do not respond to carbamazepine and oxcarbazepine or who have intolerance, addition of baclofen or lamotrigine is recommended (1). In patients who are not using other anticonvulsants, lamotrigine is typically started at $25 \mathrm{mg}$ per day for the first two weeks and increased to $50 \mathrm{mg}$ per day for the next two weeks (1).
In a systematic review published by the American Academy of Neurology and the European Federation of Neurological Associations in 2008, it was concluded that carbamazepine was effective in controlling pain in patients with classic TN, while oxcarbazepine, baclofen, lamotrigine, and pimozide were likely to be effective $(1,14)$.

Ablative procedures are recommended in patients with TN who do not respond to medical treatment. It is necessary to discuss surgical treatment options using radiofrequency thermocoagulation rhizotomy, mechanical balloon compression, radiosurgery, peripheral neurectomy, and nerve block (1). Ablative procedures are less invasive; however, relapse may be more common.

High-resolution brain MRI and magnetic resonance angiography may be useful to detect vascular compression as the etiology of classical TN (1). CISS consists of three-dimensional T2A images with high resolution $(15,16)$. The CISS sequence was first used by Casselman et al in the detailed evaluation of inner ear and cerebellopontine angle (17). High-resolution images can be obtained by providing a contrast between cranial nerve and CSF in CISS sequenced images $(18,19)$. Thin-section cranial MRI and CISS sequence cranial MRI was performed preoperatively.

According to Sweet in the literature, vascular compression of the trigeminal nerve root is the etiology of more than $80 \%$ of the TN cases (20). Hardy and Rhoton showed that in 25 cases they examined, 50 nerve roots had contact with arteries, and they stated that $87 \%$ SCA and $13 \%$ AICA created the compression in most of them (21). Janetta and Rand reported that in the transtentorial intervention performed in 5 patients with classical TN, the trigeminal nerve was severely compressed and distorted by SCA or more arterial branches, and this was a possible etiology of classical TN (22). In our preoperative study; SCA in 4 cases, AICA in 2 cases, and SCA + PV in 1 case were found to cause compression on the trigeminal nerve.

MVD is a widely accepted surgical approach in the treatment of TN with high rate of success and low risk of complications (23). Upon review of literature, in the 1995 study of Mendoza et al. it was observed that $71 \%$ of the patients were painless after the procedure (24). Another study by Broggi et al. in 2000 showed $75 \%$ postoperative relief. (25) In 2017, Gao et al. reported a $90 \%$ success rate, and in 2018 , Wei et al. reported that $93 \%$ of the patients after surgery were painless $(26,27)$. In this study, surgery was performed on patients who were resistant to medical treatment and had persistent pain despite several ablative treatments. By applying MVD; a Teflon sponge was placed between the trigeminal nerve and these pathological vascular structures. All cases were observed to be painless in the first year of follow-up.

Although MVD is an effective treatment for TN, it has potential risks for delicate cerebellopontine angle structures (23). The most common complications after MVD are mild temporary facial numbness (5.2\%), CSF leakage (4.8\%), mild 
hearing loss $(3.6 \%)$, severe hearing loss $(3.2 \%)$, and transient diplopia $(2.4 \%)(23)$. Other potential serious complications that may occur are intracerebellar hematoma, supratentorial acute subdural hematoma, status epilepticus, and subarachnoid hemorrhage (28). On the second postoperative day, CSF leakage was observed in one of the seven patients in our series. The patient was followed up for 1 week after the lumbar drainage, then it was observed that the wound site was clean.

We believe manipulation is easier in MVD as a result of the surgeon's ability to use both hands at the same time and is more effective for completing the entire decompression process.

\section{CONCLUSION}

Thin-section MRI, especially CISS sequence cranial MRI are widely used for detecting vascular structures that cause compression in patients with TN. MVD offers satisfactory results when applied to patients with $\mathrm{TN}$ who do not respond to medical treatment and are suitable for surgery.

Ethics Committee Approval: Kocaeli Derince Training and Research Hospital Clinical Research Ethics Committee (11.03.2021 / 41)

Conflict of Interest: None

Funding: None

Informed Consent: Receipt

\section{REFERENCES}

1. Kes VB, Matovina LZ. Accommodation to diagnosis of trigeminal neuralgia. Acta Clin Croat. 2017; 56: 157-161.

https://doi.org/10.20471/acc.2017.56.01.21

2. Headache Classification Committee of the International Headache Society (IHS). The International Classification of Headache Disorders, 3rd ed. (beta version). Cephalalgia. 2013; 33: 629-808. doi: 10.1177/0333102413485658.

3. Katusic S, Williams DB, Beard CM, Bergstralh EJ, Kurland LT. Epidemiology and clinical features of idiopathic trigeminal neuralgia and glosso-pharyngeal neuralgia: similarities and di erences, Rochester, Minnesota, 19451984. Neuroepidemiology. 1991; 10: 276-81. https://doi.org/10.1159/000110284

4. MacDonald BK, Cockerell OC, Sander JW, Shorvon SD. Incidence and lifetime prevalence of neurological disorders in a prospective community-based study in the UK. Brain. 2000; 123: 665-676.

https://doi.org/10.1093/brain/123.4.665

5. Bendtsen L, Zakrzewska JM, Heinskou TB, Hodaie M, Leal PRL, Nurmikko T, et al.Advances in diagnosis, classification, pathophysiology, and management of trigeminal neuralgia. Lancet Neurol. 2020; 19: 784-796. https://doi.org/10.1016/S1474-4422(20)30233-7

6. Zakrzewska JM, Wu J, Mon-Williams M, Phillips N, Pavitt $\mathrm{SH}$. Evaluating the impact of trigeminal neuralgia. Pain.
2017; 158: 1166-1174.

https://doi.org/10.1097/j.pain.0000000000000853

7. Maarbjerg S, Gozalov A, Olesen J, Bendtsen L. Trigeminal neuralgia: a prospective systematic study of clinical characteristics in 158 patients. Headache. 2014; 54: 15741582 .

https://doi.org/10.1111/head.12441

8. Love S, Coakham HB. Trigeminal neuralgia: pathology and pathogenesis. Brain. 2001; 124: 2347-2360.

https://doi.org/10.1093/brain/124.12.2347

9. Hamlyn PJ. Neurovascular relationships in the posterior cranial fossa, with special reference to trigeminal neuralgia. 2. Neurovascular compression of the trigeminal nerve in cadaveric controls and patients with trigeminal neuralgia: quantification and influence of method. Clin Anat. 1997; 10: 380-38.

https://doi.org/10.1002/(SICI)1098-2353(1997)10:6<380::AIDCA2>3.0.CO;2-T

10. Bendtsen L, Zakrzewska JM, Abbott J, Braschinsky M, Stefano GDi, Donnet A, et al. European Academy of Neurology guideline on trigeminal neuralgia. Eur J Neurol. 2019; 26: 831-849. https://doi.org/10.1111/ene.13950

11. Huang Z, Pu B, Li F, Liu K, Hua C, Li C, et al. Analysis of failed microvascular decompression in patients with trigeminal neuralgia. J Neurol Surg B Skull Base. 2020; 81: 567-571. https://doi.org/10.1055/s-0039-1692683

12. Jannetta PJ. Arterial compression of the trigeminal nerve at the pons in patients with trigeminal neuralgia. 1967. J Neurosurg. 2007; 107: 216-219. https://doi.org/10.3171/JNS-07/07/0216

13. Petty PG, Southby R, Siu K. Vascular compression: cause of trigeminal neuralgia. Med J Aust. 1980; 1: 166-167. https://doi.org/10.5694/j.1326-5377.1980.tb134736.x

14. Gronseth G, Cruccu G, Alksne J, Argoff C, Brainin M, BurchielK, etal.Practiceparameter:thediagnosticevaluation and treatment of trigeminal neuralgia (an evidence-based review): report of the Quality Standards Sub-committee of the American Academy of Neurology and the European Federation of Neurological Societies. Neurology. 2008; 71: 1183-1190. https://doi.org/10.1212/01.wnl.0000326598.83183.04

15. Hatipoğlu HG, Durakoğlugil T, C1lız D, Yüksel E. Arka fossa sinirlerinin MR sisternografi ile değerlendirilmesi. Diagn Interv Radiol. 2007; 13: 56-60.

16. Yıldız S, Kaya A. Epidermoid tümörün görüntülenmesinde ve araknoid kistten ayırıcı tanısında CISS MRG sekansının rolü. Tani Girisim Radyol. 2002; 8: 3-9.

17. Casselman JW, Offeciers FE, Govaerts PJ, Kuhweide R, Geldof H, Somers T, et al. Aplasia and hypoplasia of the ves- tibulocochlear nerve: diagnosis with MR imaging. Radiology. 1997; 202: 773-781. 
https://doi.org/10.1148/radiology.202.3.9051033

18. Yousry I, Camelio S, Schmid UD, Horsfield MA, Wiesmann M, Bruckmann H, et al. Visualization of cranial nerves I-XII: value of 3D CISS and T2-weighted FSE sequences. Eur Radiol. 2000; 10: 1061-1067. https://doi.org/10.1007/s003300000452

19. Kakızawa Y, Hongo K, Takasawa H, Miyairi Y, Sato A, Tanaka $\mathrm{Y}$, et al. 'Real' three dimensional constructive interference in steadystate imaging to discern microneurosurgical anatomy. Technical note. J Neurosurg. 2003; 98: 625-630. https://doi.org/10.3171/jns.2003.98.3.0625

20. Sweet WH, Wepsic SG. Controlled thermocoagulation of trigeminal ganglion and rootlets for differential destruction of pain fibers. Part 1: Trigeminal neuralgia. J Neurosurg. 1977; 40: 143-156.

https://doi.org/10.3171/jns.1974.40.2.0143

21. Hardy DG, Rhoton AL. Microsurgical relationships of the superior cerebellar artery and the trigeminal nerve. J. Neurosurg. 1978; 49: 669-678.

https://doi.org/10.3171/jns.1978.49.5.0669

22. Jannetta PJ. Arterial compression of the trigeminal nerve at the pons in patients with trigeminal neuralgia. J Neurosurg. 1967; 26: 159-162.

https://doi.org/10.3171/jns.1967.26.1part2.0159

23. Xia L, Zhong J, Zhu J, Wang YN, Dou NN, Liu MX, et al. Effectiveness and safety of microvascular decompression surgery for treatment of trigeminal neuralgia: a systematic review. J Craniofac Surg. 2014; 25: 1413-1417. https://doi.org/10.1097/SCS.0000000000000984

24. Mendoza N, Illingworth RD. Trigeminal neuralgia treated by microvascular decompression: a long-term follow-up study. Br J Neurosurg. 1995; 9: 13-19. https://doi.org/10.1080/02688699550041692

25. Broggi G, Ferroli P, Franzini A, Servello D, Dones I. Microvascular decompression for trigeminal neuralgia: comments on a series of 250 cases, including 10 patients with multiple sclerosis. J Neurol Neurosurg Psychiatry. 2000; 68: 59-64. https://doi.org/10.1136/jnnp.68.1.59

26. Gao J, Fu Y, Guo SK, Li B, Xu ZX. Efficacy and prognostic value of partial sensory rhizotomy and microvascular decompression for primary trigeminal neuralgia: a comparative study. Med Sci Monit. 2017; 23: 2284-2291. https://doi.org/10.12659/MSM.901510

27. Wei Y, Pu C, Li N, Cai Y, Shang H, Zhao W. Long-term therapeutic effect of microvascular decompression for trigeminal neuralgia: Kaplan-Meier analysis in a consecutive series of 425 patients. Turk Neurosurg. 2018; 28: 88-93.

28. HanakitaJ,KondoA.Seriouscomplicationsofmicrovascular decompression operations for trigeminal neuralgia and hemifacial spasm. Neurosurgery. 1988; 22: 348-352. https://doi.org/10.1227/00006123-198802000-00012 